\title{
The regulatory framework for foreign investment in Turkey
}

\author{
by Associate Professor Arslan Kaya and Dr Mehmet Nâfi Artemel
}

The authors explain recent reforms to the Turkish foreign investment regime.

\section{LEGISLATIVE FRAMEWORK}

$\mathrm{T}$ The Turkish foreign investment regime has undergone a substantial overhaul with the enactment of the "Foreign Direct Investment Law" (Law 4875; hereinafter referred to as the FDI Law). The new FDI Law came into effect on June 17, 2003, superseding "Law 6224 Concerning the Encouragement of Foreign Capital". The latter, which we shall henceforth refer to in the text as Law 6224, had been in force since 1954 , and was essentially drafted in the spirit of favouring incentives as a principal means of attracting foreign capital inflow. In many respects, Law 6224, in retrospect, appears to be a fairly liberal one, even when judged by today's standards. For instance, the repatriation of profits or the principle of equal treatment seem to have been at the forefront of the facilities offered to prospective foreign investors.

The new FDI Law reflects instead the internationally recognised criteria in laying the groundwork for a setting that is amenable to foreign investment. The rationale for the FDI Law finds its expression at Article 1, where it is stated that the purpose of the Law is to attract foreign direct investment by means of complying with internationally recognised standards, and to replace the approval based system with one based on notification.

\section{COMPETENT AUTHORITY OVERSEEING FOREIGN DIRECT INVESTMENTS}

The Undersecretariat of the Treasury (the "Undersecretariat") has been designated as the ultimate authority in respect of matters related to direct foreign investments in Turkey. However, in practice it is the General Directorate of Foreign Investment (GDFI) that is entrusted with providing services in connection with foreign investments. The new legislation has, on the other hand, assigned the Undersecretariat a more proactive role, in that the latter is entrusted with the responsibility of developing policies and strategies with a view to identifying and promoting direct foreign investment opportunities in Turkey. This it does by by liaising with public institutions and representatives of the private sector establishments.

Having removed the requirement for prior permission or authorisation in respect of foreign investments to be made in Turkey, the FDI Law has empowered the Undersecretariat to request information from public authorities and professional bodies for the purpose of gathering and compiling pertinent statistics. Article 4 of the new legislation specifically provides that such information is to be collected for mere statistical purposes and that it is not to be used for evidentiary purposes.

\section{FUINDAMENTAL CONCEPTS INTRODUCED BY THE FDI LAW}

Two concepts, it is suggested, that are fundamental to an understanding of any foreign investment law are "foreign investment" and "foreign investor". These two terms have been defined in Article 2 of the FDI Law, with reference to their connotations in accordance with internationallyrecognised foreign direct investment criteria.

\section{Foreign investor}

As an umbrella term, a foreign investor is used in the FDI Law as referring to a foreign national or a Turkish citizen who is resident abroad or legal entities and international institutions that are established pursuant to the laws of foreign countries, who make a direct foreign investment in Turkey.

An interesting feature of the FDI Law is the explicit reference made to Turkish citizens who are resident abroad. According to Article 10 of the Regulations for the Implementation of the FDI Law (published in the Official Gazette, No. 25205, dated 20 August 2003 - the statute shall hereafter be referred to as the "Implementing Regulations") a Turkish citizen shall for the purposes of the FDI Law, qualify as a 'foreign investor', where documentary evidence in the form of a residence or work permit that attests to the residence abroad is provided. Since the only proviso is that of residence, the FDI Law does not distinguish whether the person is in possession of dual citizenship or not. Accordingly, the funds that a Turkish national brings from the country in which he resides, shall equally be treated as capital inflow for the purposes of the FDI Law, where that person wishes to use such funds for the purpose of making a direct foreign investment in Turkey. 
The FDI Law thus paves the way for local companies domiciled in Turkey to channel funds indirectly through a Turkish national residing abroad back into the country in the form of direct foreign investments.

\section{Foreign direct investment}

Under the FDI Law, foreign direct investment can be effected either through the medium of assets brought into Turkey from abroad or alternatively through those procured from within the country. Foreign direct investments that are brought into Turkey by the foreign investor refer to monetary capital in the form of convertible money that is bought and sold by the Central Bank of Turkey, stocks and bonds, with the exception of government bonds, machinery and equipment, and industrial and intellectual property rights.

A foreign investor shall be deemed as having made a direct foreign investment where he establishes a company or a branch office in Turkey by means of bringing in the aforesaid assets; or participates in an existing company by means of acquiring shares other than on the financial stock exchange; or acquires at least a 10 per cent shareholding on the financial stock exchange or the equivalent voting.

The companies which a foreign investor may establish or invest in are companies that are listed in the Turkish Commercial Code, and unincorporated partnerships that are defined in the Turkish Code of Obligations. Notwithstanding the contractual relationship on which they are based, partnerships such as ordinary partnerships, consortiums, business partnerships or joint ventures that lack the requisite legal characteristics of a company as defined by the Turkish Commercial Code are treated as unincorporated partnerships for the purposes of the FDI Law.

Foreign direct investment may also consist of establishing a new company or a branch office; or participating in an existing company by means of acquiring shares other than on the financial stock exchange; or acquiring a minimum 10 per cent shareholding on the financial stock exchange or the equivalent voting power by means of reinvesting the value of capital in the form of profits, sale proceeds, receivables or other pecuniary rights deriving from an investment and rights concerning the commercial exploration and exploitation of natural resources.

\section{PRINCIPAL FEATURES OF THE FDI LAW}

\section{Unfettered investment opportunities for the foreign investor who will enjoy non-discriminatory treatment}

Article 3 (a) of the FDI Law expressly provides that unless otherwise contrary to international conventions or specific local laws, all foreign investors shall enjoy complete freedom in making a direct foreign investment in Turkey.
Moreover, in accordance with the aforementioned article, a foreign investor shall be subject to exactly the same treatment as that which a Turkish investor would. The FDI Law, in this respect, reiterates the equal treatment principle that had already existed in the predecessor to the present legislation, albeit having been differently worded. Under the descriptive heading of "Equal Treatment for National and Foreign Capital”, Article 10 of Law 6224 stipulated that, "All rights, exemptions and privileges granted to national capital and to local enterprises shall be available under the same conditions to foreign capital and to non-domestic firms involved in the same area of business."

\section{Measures to safeguard foreign direct investments from the risk of nationalisation or expropriation.}

The FDI Law, possibly with a view to reassure prospective foreign investors, specifically deals with this matter under a separate heading at Article 3. Pursuant to this provision, unless deemed to be against the public interest in accordance with the appropriate legislation in force at the time, a direct foreign investment shall neither be subject to nationalisation nor expropriation. Furthermore, in the event that either of the latter acts is executed on the ground of public interest, due compensation shall have to be made accordingly.

\section{Repatriation of funds}

In accordance with Article 3 (c) of the FDI Law, foreign investors can freely transfer abroad profits, dividends, proceeds from the sale or liquidation of all or part of any investment, payments received under a licence, management or similar agreement, as well as repayments of foreign credit principal and interest through a bank or other appropriate financial institution.

The transfer regime brought in by virtue of the FDI Law is significantly wider in scope than that of Decree 32 on the "Protection of the Value of Turkish Currency" in terms of recognising the range of investment tools, such as sale and purchase of shares or trading on the stock exchange, from which proceeds may be derived and repatriated.

\section{Acquisition of immovable property}

Foreign investors are entitled to acquire title in real estate through a legal entity that they have established on their own account in Turkey, or through one in which they hold an equity, over and in any land that a Turkish national would be entitled to.

Neither the Turkish "Villages Act" nor the Law on Title Deeds, place any restrictions on a Turkish company from purchasing real estate. As mentioned above, since a foreign company established in Turkey, or similarly one that participates in a Turkish company shall be deemed to be a Turkish company for the purpose of this law, that company shall equally benefit from the fact that the above- 
mentioned laws are silent on acquisitions of real estate by Turkish legal entities.

A company may acquire title to real estate in Turkey, pursuant to Article 137 of the Turkish Commercial Code, only where this does not amount to an ultra vires act and where the objects clause of the company's Memorandum of Association empowers it to do so. A foreign capital company that is deemed to be a Turkish one by virtue of its domicile shall be equally subject to the provisions of Article 137.

With regard to acquisitions of real estate by foreign real persons or partnerships that are devoid of legal entity status, the principle of reciprocity shall prevail.

\section{International arbitration}

The FDI Law, whilst enabling foreign investors to have recourse to national courts, makes provision for national or international arbitration and other dispute resolution mechanisms in circumstances where a dispute has arisen in connection with a contract for investment that is governed by private law, or an agreement entered into with a public authority under which concessions concerning public services had been granted, provided the conditions stipulated in the pertinent statutes have materialised and the parties have both agreed to that effect.

In accordance with the provisions of the International Arbitration Act (Law 4686) which came into effect on July 5, 2001, only real or legal persons can resort to arbitration as against public bodies over disputes concerning public services. The FDI Law, on the other hand, allows for the settlement of disputes of any nature that may arise between foreign investors and public bodies.

\section{Employment of foreign personnel}

Foreign nationals to be employed by companies, branches, or other organisations established in Turkey in accordance with the provisions of the FDI Law, shall be provided with a work permit by the Ministry of Labour and Social Security (Art $2(\mathrm{~g})$ ).

The Implementing Regulations to the "Law 4817 regulating the grant of work permits to Aliens" (first published in the Official Gazette dated August 29, 2003, subsequently amended and published in the Official Gazette of April 24, 2004), define further which foreign entities shall be deemed to come within the scope of the above Regulations. The latter also addresses the conditions under which work permits may be granted to the foreign "key personnel” for which a definition has been provided.

The FDI Law exempts aliens from the conditions laid down in Article 14 (b) of Law 4817, which stipulates that an application by a foreigner for a work permit or for renewal of one that has expired shall be rejected where within four weeks of the date when the vacancy has first been advertised, a candidate from within Turkey with the requisite qualifications for the particular job has applied for the post in question.

\section{Removal of restrictions on foreign investments}

A fundamental feature of the new FDI Law is that it abolishes the requirement by prospective foreign investors to obtain the prior approval of the GDFI. One exception remains, as discussed below, concerned with the setting up of liaison offices in Turkey.

General rule: the removal of the requirement for prior approval

Although foreign investors need no longer seek the permission of the GDFI before engaging in direct foreign investments in Turkey, they shall nonetheless be required instead to - as it is worded in the law itself (Art 1) "inform" the GDFI. Turkish companies are similarly under a duty to inform the GDFI, where and whenever such a company happens to incorporate a foreign interest.

All foreign investment as defined under Law 4875, irrespective of the activities undertaken, require submission of information

Some of the instances in which foreign investors under the now repealed Law 6224 and other pertinent laws would have had to apply for permission to GDFI, but no longer need to do so, may be listed as follows:

- formation of a new company or a branch office in Turkey;

- participation in local companies, engagement in investments in Turkey;

- any change in the nature of activities undertaken by the foreign company in Turkey;

- increase of share capital and transfer of shares within the company;

- registration of licensing, know-how, technical assistance, and franchising agreements.

Thus, in order to establish a new company in Turkey, the investor shall not as under the former law be required to first apply for a permission from the GDFI, but merely follow the same procedure as that required for forming a Turkish company. Since foreign companies that are established or to be established in Turkey shall be deemed to be Turkish companies, their rights and liabilities shall accordingly be determined within the framework of the Turkish Commercial Code and other pertinent legislation applicable to Turkish companies.

\section{Nature of information to be supplied to the GDFI}

Companies or branch offices that are regulated by the FDI Law

A company or branch office that is recognised as such in accordance with the provisions and for the purpose of the FDI Law is required to submit the following documents to the GDFI:

(i) Information pertaining to capital invested as well as to activities undertaken in Turkey, in respect of the 
previous year, has to be submitted on the pre-printed "FDI Operations Data Form", annually before the end of May in that year.

(ii) Details concerning payments made into capital account on the "FDI Capital Data Form" within one month of such payments having been effected.

(iii)Details relating to transfer of shares effected between a Turkish partner and its foreign counterpart or that made to a Turkish or foreign investor outside the company on the "FDI Share Transfer Data Form" within one month of the transfer.

\section{Turkish companies not regulated by the FDI Law (those consisting of exclusively Turkish capital)}

A Turkish company shall likewise be required to provide information on a form identical to that mentioned in paragraph (iii) above (ie "FDI Share Transfer Data") where either of the following should occur:

(i) A foreign investor participates in the existing Turkish company, or

(ii) A foreign investor from outside the company contributes to the increase of the authorised share capital in that Turkish company.

Since a wholly Turkish capital owned company will be caught by the provisions of the FDI Law upon the occurrence of either of the above, it shall accordingly be required to submit to the GDFI information concerning the transfer of shares.

The removal of the requirement for minimum capital inflow threshold

Under the former law, there existed a requirement that each foreign investor had to bring into the country a minimum of US\$ 50,000 in order to establish a company or to be eligible to invest in Turkey in general. Furthermore, foreign individuals or entities were not permitted to establish companies other than corporations or limited liability companies. The new FDI Law has not only abolished the minimum foreign capital requirement but has also removed any restrictions as to the type of company which foreign investors may wish to form in Turkey.

It should be noted, however, that foreign companies in existence before the coming into force of the new FDI Law as well as those established thereafter, need to comply, as any local Turkish company, with the requirements of the Turkish Commercial Code and other pertinent laws, as well as obtaining such approvals as may be necessary during the course of their activities in Turkey.

\section{LIAISON OFFICES: AN EXCEPTION TO THE GENERAL RULE WHERE THE REQUIREMENT FOR PRIOR APPROVAL SURVIVES}

Article 6 of the Implementing Regulations empowers the Undersecretariat with the authority to process applications and grant or renew permits to set up liaison offices in Turkey, provided that the liaison offices refrain from conducting commercial activities.

Applications to set up a liaison office or for renewal of permissions are, as it is stipulated in the aforementioned article, to be processed within five working days from the date the application has been filed. Applications by foreign companies wishing to set up liaison offices for the purpose of conducting activities in areas regulated by legislation specific to that field of activity - such as money, capital markets or the insurance industry - shall on the other hand be considered by the competent body designated under the relevant legislation.

\section{Application procedure}

The application to set up a liaison office in Turkey has to be submitted to the Under-secretariat, accompanied by the following documentation:

(i) A certificate of activity, duly certified by the appropriate Turkish Consulate or according to the provisions of the Convention Abolishing the Requirement of Legalisation for Foreign Public documents, prepared within the framework of the Hague Convention on Private International Law

(ii) The company's annual report or its balance sheet and income accounts.

(iii)A certificate of authorisation issued in the name of the person who will be in charge of running the liaison office.

(iv) Where the formalities in connection with setting up a liaison office in Turkey are carried out by an individual other than the person mentioned in paragraph (b) above, a power of attorney duly authorising that individual for such purposes.

\section{Filing requirements of liaison offices}

(i) Within one month of obtaining the requisite permission to set up a liaison office, a copy of the tax registration certificate must be filed with the GDFI. Should the liaison office happen to move to a new address, the GDFI must be notified of the office's new address within a month of the move having taken place.

(ii) Liaison offices are required to submit to the Undersecretariat information relating to the activities of the office in the previous year by the end of May for each corresponding year. The so-called "Data Form for Liaison Offices" on which the requisite information is 
supplied has to be submitted together with other supporting documents evidencing that all expenses incurred by the liaison office, in connection with its activities in the preceding year, have been paid for by means of funds transferred to Turkey from abroad.

(iii) The term of the permit granted to a liaison office may not exceed a three-year period. Thereafter, in respect of each application for the renewal of the permit - not exceeding three years each - the Undersecretariat shall carry out an evaluation as to the activities of the office in the preceding year, as well as its projected strategies and future objectives.

(iv) A liaison office that wishes to bring to an end its activities in Turkey needs to notify the GDFI by means of submitting to the latter a release form obtained from the appropriate tax office with which the office is registered. Upon its closure or liquidation, a liaison office shall only be entitled to transfer abroad the resulting proceeds.

(v) The Undersecretariat reserves the right to withdraw the permission it may have granted to a liaison office, where it considers that the office has fallen foul of the pertinent rules and regulations, and shall accordingly inform the relevant authorities of its decision.

\section{Will the FDI Law be a panacea for Turkey's economic woes?}

The FDI Law is expected to hail a new era in attracting significant capital inflows into the country. The legislation certainly goes some way towards eliminating most of the obstacles and red tape which was generally considered to be a considerable deterrent by potential foreign investors. The abolition of the requirement to obtain prior approval and its replacement by a notification procedure for the purpose of gathering and building a statistical database may send a positive signal to prospective foreign investors in that it may be seen as indicative of the political will behind the new measures.

On the other hand, it is suggested that legislation alone, however accommodating in terms of the removal of barriers or conversely in terms of providing incentives and exemptions, is unlikely to be the sole motive for foreign direct investment in a country. Political as well as macroeconomic factors are just as important as a sound legislative framework designed to facilitate the inflow of foreign capital. The Customs Union in operation since 1996 between Turkey and the EU, perhaps on account of such reasons, did not attract significant capital as compared to Eastern European countries.

It remains to be seen whether the FDI Law will contribute to a dramatic increase in foreign direct investment which previous governments, much like the present one, have considered to be a remedy for the country's ailing long-standing economic difficulties. On the other hand, adoption of a considerably liberal FDI Law, at a time when later this year Turkey expects to be given a date for commencing accession negotiations with the EU, may be interpreted as a sign that the country is at least doing all it can to reap the benefits of successive waves of foreign direct investment. (c)

\section{Associate Professor Arslan Kaya}

Associate Professor of Commercial Law, Faculty of Law, Istanbul University

Dr Mehmet Nâfi Artemel

Lecturer in Law and Communications, Management Department, Boğaziçi University 